Article

\title{
Numerical Simulation Analysis of Ag Crystallite Effects on Interface of Front Metal and Silicon in the PERC Solar Cell
}

\author{
Myeong Sang Jeong ${ }^{1}$, Yonghwan Lee ${ }^{2} \mathbb{D}$, Ka-Hyun Kim ${ }^{3} \mathbb{D}$, Sungjin Choi ${ }^{1}$, Min Gu Kang ${ }^{1}$ and Soo Min Kim ${ }^{2, *}$ \\ and Hee-eun Song $1, *(\mathbb{D}$
}

1 Photovoltaic Laboratory, Korea Institute of Energy Research, Daejeon 34129, Korea; jmsang@kier.re.kr (M.S.J.); sjchoi@kier.re.kr (S.C.); mgkang@kier.re.kr (M.G.K.)

2 Convergence Materials Research Center, Innovative Technology Research Division, Gumi Electronics and Information Technology Research Institute (GERI), Gumi 39171, Korea; yhlee@geri.re.kr

3 Department of Physics, Chungbuk National University, Cheongju 28644, Korea; kahyunkim@chungbuk.ac.kr

* Correspondence: smkim83@geri.re.kr (S.M.K.); hsong@kier.re.kr (H.-e.S.); Tel.: +82-54-470-2128 (S.M.K.); +82-42-860-3492 (H.-e.S.)

check for updates

Citation: Jeong, M.S.; Lee, Y.; Kim, K.-H.; Choi, S.; Kang, M.G.; Kim, S.M.; Song, H.-e. Numerical Simulation Analysis of Ag Crystallite Effects on Interface of Front Metal and Silicon in the PERC Solar Cell. Energies 2021, 14, 592. https://doi.org/ 10.3390/en14030592

Academic Editor: Claudia Barolo Received: 28 December 2020 Accepted: 14 January 2021 Published: 25 January 2021

Publisher's Note: MDPI stays neutral with regard to jurisdictional clai$\mathrm{ms}$ in published maps and institutional affiliations.

Copyright: (C) 2021 by the authors. Licensee MDPI, Basel, Switzerland. This article is an open access article distributed under the terms and conditions of the Creative Commons Attribution (CC BY) license (https:// creativecommons.org/licenses/by/ $4.0 /)$.

\begin{abstract}
In the fabrication of crystalline silicon solar cells, the contact properties between the front metal electrode and silicon are one of the most important parameters for achieving high-efficiency, as it is an integral element in the formation of solar cell electrodes. This entails an increase in the surface recombination velocity and a drop in the open-circuit voltage of the solar cell; hence, controlling the recombination velocity at the metal-silicon interface becomes a critical factor in the process. In this study, the distribution of Ag crystallites formed on the silicon-metal interface, the surface recombination velocity in the silicon-metal interface and the resulting changes in the performance of the Passivated Emitter and Rear Contact (PERC) solar cells were analyzed by controlling the firing temperature. The Ag crystallite distribution gradually increased corresponding to a firing temperature increase from $850{ }^{\circ} \mathrm{C}$ to $950{ }^{\circ} \mathrm{C}$. The surface recombination velocity at the silicon-metal interface increased from 353 to $599 \mathrm{~cm} / \mathrm{s}$ and the open-circuit voltage of the PERC solar cell decreased from 659.7 to $647 \mathrm{mV}$. Technology Computer-Aided Design (TCAD) simulation was used for detailed analysis on the effect of the surface recombination velocity at the silicon-metal interface on the PERC solar cell performance. Simulations showed that the increase in the distribution of Ag crystallites and surface recombination velocity at the silicon-metal interface played an important role in the decrease of open-circuit voltage of the PERC solar cell at temperatures of $850-900{ }^{\circ} \mathrm{C}$, whereas the damage caused by the emitter over fire was determined as the main cause of the voltage drop at $950{ }^{\circ} \mathrm{C}$. These results are expected to serve as a steppingstone for further research on improvement in the silicon-metal interface properties of silicon-based solar cells and investigation on high-efficiency solar cells.
\end{abstract}

Keywords: passivated emitter and rear contact solar cell; numerical simulation analysis; Ag crystallite; silicon-metal interface; surface recombination; TCAD

\section{Introduction}

Among the recent trends of research in the photovoltaic industry, a Passivated Emitter and Rear Contact (PERC) structure that minimizes surface recombination through passivation layers on the front and rear sides of a solar cell has gained considerable interest. The front-side recombination of PERC solar cells directly impact the open-circuit voltage of solar cells and is one of the key factors affecting the efficiency loss of solar cells. This frontside recombination is represented as leakage current in reverse direction on the equivalent circuit, and the leakage current is defined as saturation current density. In a solar cell structure, differences arise in the diffusion length according to the absorption coefficient of the solar spectrum, and with the sunlight entering the silicon substrate, the absorption rate decreases, which leads to an exponential decrease in the photogeneration rate, and thus the 
saturation current density is the highest at the front-side of the solar cell. The surface recombination velocity has the highest value at the electrode part at the front-side of the solar cell, and thus the highest value is observed at saturation current density $\mathrm{J}_{0 \text {.metal }}$ occurring at the electrode [1-3]. The high value of $\mathrm{J}_{0 . \text { metal }}$ reduces the open-circuit voltage of solar cells; reducing $\mathrm{J}_{0 . m e t a l}$ is one of the pivotal factors in the manufacturing of high-efficiency solar cells [4-9]. In this context, while most research on solar cell efficiency enhancement has been conducted to date on the passivation properties of solar cells, as research with this approach is reaching its limit, there is a need for research with a strategic approach that focuses on reducing the recombination by electrodes.

In general, in crystalline silicon-based PERC solar cells, the front electrode is fabricated through a screen printing process. In the formation process of the front electrode, $\mathrm{Ag}$ paste is patterned in a grid form on the front surface of the silicon on which the $\mathrm{SiN}_{x}$ passivation layer is formed, and then the electrode undergoes a firing process to complete the fabrication. In the firing process, the glass frit inside the $\mathrm{Ag}$ paste is fluidized and reacts with the front-side $\mathrm{SiN}_{x}$ passivation layer, leading to fire through reaction. It has been reported that Ag crystallites are formed on the surface of the Si substrate in the fire through a reaction process, forming contacts with the emitter layer [10,11]. Ag crystallites formed in this way reduce the glass layer resistance formed by the firing process through reaction and they are regarded as an important element for achieving low contact resistance [12-14]. However, the Ag crystallites formed during the firing process may damage the emitter layer depending on the size and distribution. Such damage will lead to an increase in $\mathrm{J}_{0 \text {.metal }}$, a decrease in shunt resistance, and consequently degrading the solar cell performance [15].

In this study, the characteristics of $\mathrm{Ag}$ crystallites formation according to the electrode firing temperature of the solar cell were analyzed, and the effects of the changes in $\mathrm{J}_{0 \text {.metal }}$ and surface recombination velocity on the electric properties of the silicon-based PERC solar cell were investigated. To obtain the electrical properties and $\mathrm{J}_{0 \text {.metal }}$ value of the solar cell, the Suns-Voc was measured using various front metal pattern, and the values were obtained using the one-diode model. This method extracts the values using the fraction of the electrode area and the slope of $\mathrm{J}_{0 . \text { total }}[8,16,17]$. In addition, after the electrode formation, the $\mathrm{Ag}$ crystallites on the silicon surface were observed using scanning electron microscopy (SEM). With the extracted $\mathrm{J}_{0 . m e t a l}$ value, surface recombination velocity was calculated using an equation, and based on the result, the effect of the metal-silicon contact on the electrical properties of the solar cell was analyzed through simulation.

\section{Materials and Methods}

\subsection{Solar Cell Preparation}

As shown in Figure 1a, the wafer used in the experiment was a p-type $\mathrm{Cz}$ (Czochralski)Si wafer of 6 inches, resistivity at $1-3 \Omega \cdot \mathrm{cm}$, and thickness around $180 \mu \mathrm{m}$. As shown in Figure $1 \mathrm{~b}$, the wafer texturing was performed using an alkaline solution, and then with a $\mathrm{POCl}_{3}$ source, an emitter layer with sheet resistivity of about $85 \Omega$ /sq was formed in a doping furnace. After forming the emitter layer, one side etching was performed using a wet isolation process, and the Phosphorus Silicate Glass (PSG) formed in the doping process was removed by immersion in a $10 \% \mathrm{HF}$ solution for $30 \mathrm{~s}$. The passivation layer was deposited using plasma enhanced chemical vapor deposition (PECVD) and atomic layer deposition (ALD) with $\mathrm{SiN}_{x}(80 \mathrm{~nm})$ on the front surface and $\mathrm{Al}_{2} \mathrm{O}_{3} / \mathrm{SiN}_{x}(10 / 150 \mathrm{~nm})$ on the rear surface. After the laser opening process for forming the local back surface field (BSF) on the rear side, the electrode was printed using a screen printing method. 


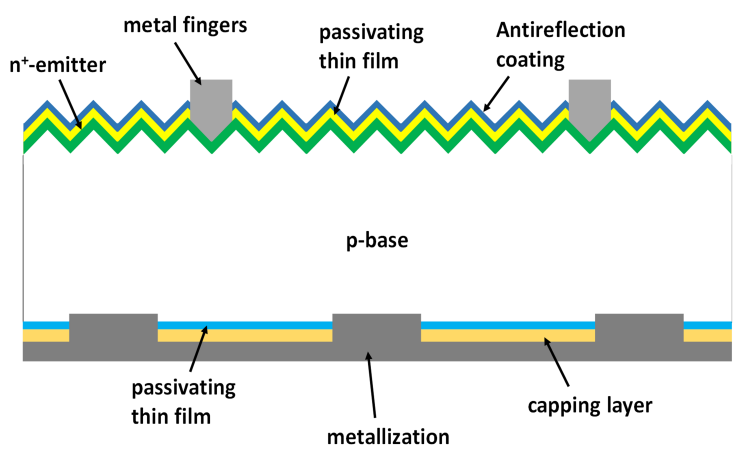

(a)

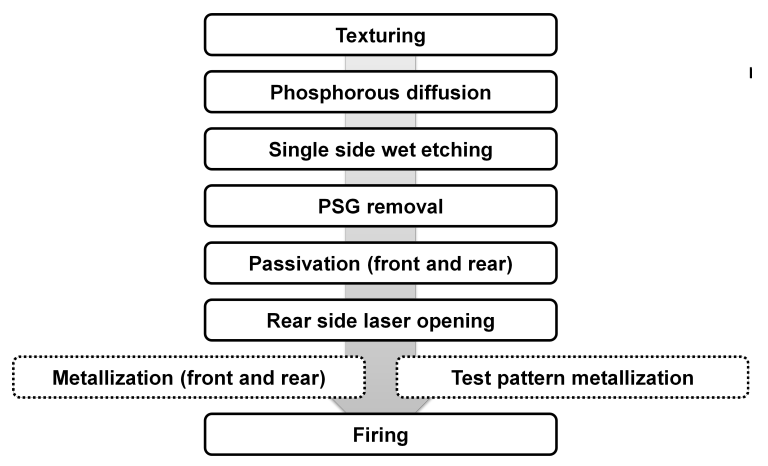

(b)

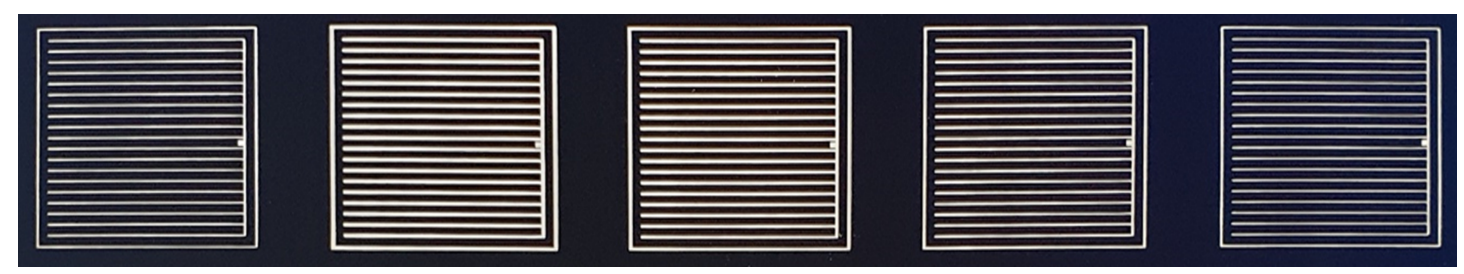

(c)

Figure 1. Passivated Emitter and Rear Contact (PERC) solar cell sample preparation, (a) PERC solar cell structure, (b) PERC solar cell manufacturing process, (c) metal pattern for measuring $\mathrm{J}_{0 . m e t a l}$.

Screen printing was conducted under two conditions: (1) preparation of the PERC solar cell and (2) preparation of $\mathrm{J}_{0 . \text { metal }}$ measurement sample. As shown in Figure $1 \mathrm{c}$, in the case of the sample for $\mathrm{J}_{0 \text {.metal }}$ measurement, the $\mathrm{H}$-pattern was printed with approximately a $4 \%$ fraction on the front surface using $\mathrm{Ag}$ paste. In addition, in the same way as the preparation of the PERC solar sample, Al paste was used for rear side printing, and for the front-side, the electrode pattern with 1-15\% fraction was used for printing. The size of each electrode pattern was $2 \mathrm{~cm} \times 2 \mathrm{~cm}$, and 25 electrode patterns were printed on one side of the wafer. All samples were printed and subjected to a high-temperature firing process at three different temperatures: 850 , which is the standard temperature, 900 and $950{ }^{\circ} \mathrm{C}$. The samples with different firing temperatures were used to investigate the firing temperature effects on the Ag crystallite distribution and $\mathrm{J}_{0 \text {.metal }}$ values. It is noted that our firing temperature has to be higher than $800{ }^{\circ} \mathrm{C}$ due to the fact that the lower firing temperature cannot appropriately form the electrically connected Ag electrode on the emitter region in silicon [18]. The diagram for the process of both samples is shown in Figure $1 \mathrm{~b}$. The electrical properties of the manufactured PERC solar cell were investigated using a light-biased current-voltage (LIV) measurement system. For the $\mathrm{J}_{0 . \text { metal }}$ sample, saturation current density was measured using a Suns-Voc testing system and this value was used to calculate the recombination velocity.

\subsection{Solar Cell Simulation Define}

In this study, for analysis of the impact on Ag crystallites distribution by firing temperature acquired experimentally, a numerical simulation method was used for systematic analysis. As shown in Figure 2, the the PERC solar cell structure was defined in a simple form to perform the simulation. A Technology Computer-Aided Design (TCAD) simulation program (Silvaco TCAD; ATLAS) was used for the solar cell simulation in this study. As for the simulation setup, a periodic boundary condition was assumed, and the repeated structure inside the solar cell was simplified for definition. For the reference solar cell of the simulation model, the thickness was defined at $170 \mu \mathrm{m}$ and the width at $725 \mu \mathrm{m}$. The basic width of the front electrode was $65 \mu \mathrm{m}$ and considering the periodic boundary condition, half of the width at $32.5 \mu \mathrm{m}$ was set for the simulation. The rear electrode was set with the structure in the same pattern as in the front electrode, and the width was also 
set to be the same as the front electrode. At the lower part of the front electrode of the simulation model, surface recombination velocity was defined, and the data obtained from the experiment was used to investigate the change pattern. The surface recombination velocity was defined under the front electrode of the simulation model, and the change pattern was tracked by applying the experimentally extracted data.

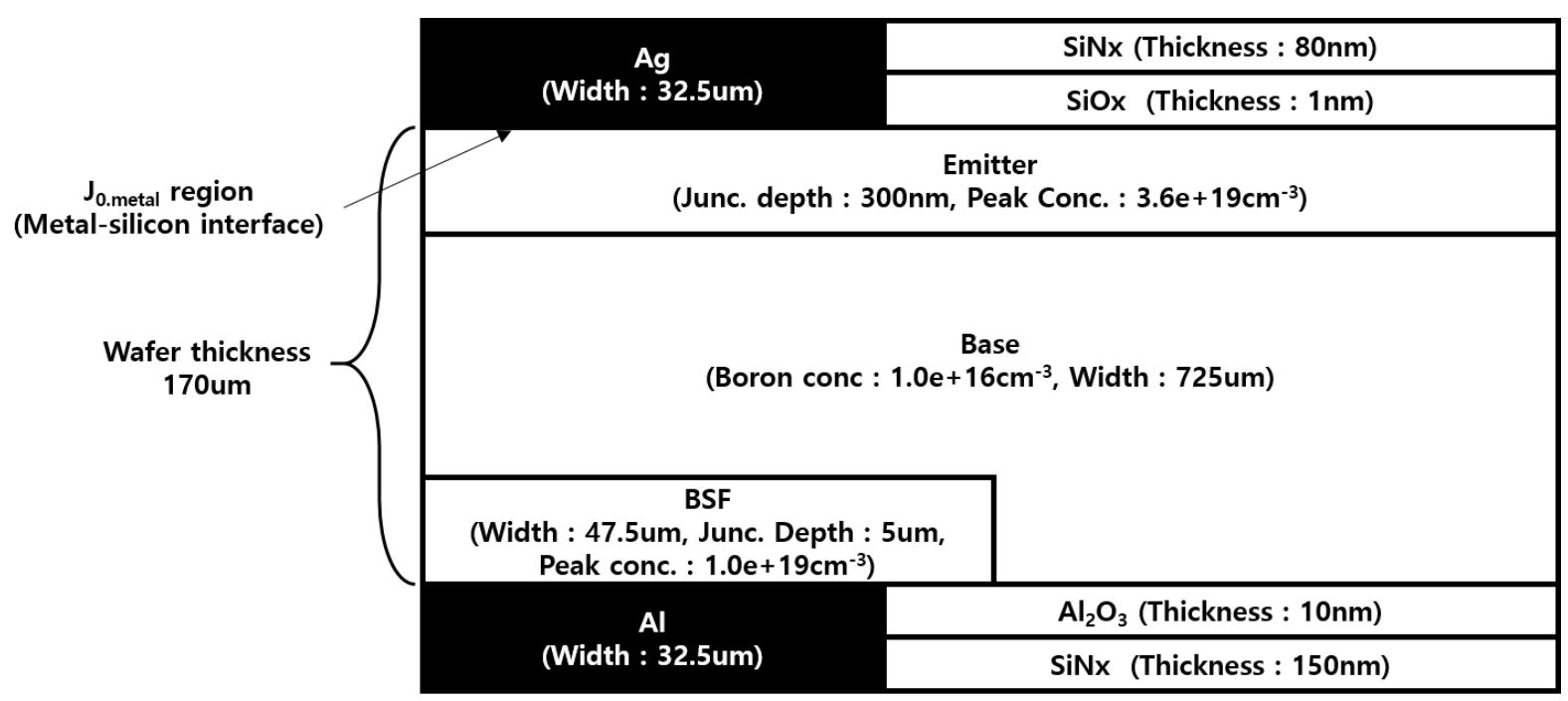

Figure 2. Schematic diagram and definition of periodic boundary domain on simplified PERC solar cell structure to perform a Technology Computer-Aided Design (TCAD) simulation for numerical calculation.

The stack passivation conditions used in the actual process were applied to define the properties of the front/rear side anti-reflection coating layer. The front-side of the solar cell was defined with a $\mathrm{SiN}_{x} / \mathrm{SiO}_{x}$ structure, at depths of $80 \mathrm{~nm}$ and $1 \mathrm{~nm}$, respectively. The rear side of the solar cell was defined with an $\mathrm{Al}_{2} \mathrm{O}_{3} / \mathrm{SiN}_{x}$ structure, at depths of $10 \mathrm{~nm}$ and $150 \mathrm{~nm}$, respectively. For the doping condition of the front emitter, the junction depth was set at $300 \mathrm{~nm}$ and the peak concentration at $3.6 \times 10^{19} \mathrm{~cm}^{-3}$. In the case of the front emitter, the distribution spans across the entire simulation domain, but in case of local BSF, the width was limited due to the local opening. The width of the local BSF was set at $47.5 \mu \mathrm{m}$ and the junction depth was set at $5 \mu \mathrm{m}$. The peak concentration of BSF was defined at $1.0 \times 10^{19} \mathrm{~cm}^{-3}$, and a Gaussian distribution was used for the impurity concentration distribution on the front and rear sides.

\subsection{Calculation of Surface Recombination Velocity}

Next, the $\mathrm{J}_{0 \text {.metal }}$ value was extracted by Suns-Voc measurement. The $\mathrm{J}_{0 \text {.metal }}$ of the PERC solar cell can be extracted by fitting the saturation current density value according to the metal fraction. In this case, $\mathrm{J}_{0 . m e t a l}$ can be calculated using the following equation [16].

$$
\begin{gathered}
J_{0 . t o t a l}=J_{0 . b u l k}+J_{0 . \text { rearmetal }}+J_{0 . \text { rearpass }}+J_{0 . \text { frontmetal }}(f)+J_{0 . \text { frontpass }}(1-f) \\
\text { Slope }=J_{0 . \text { frontmetal }}-J_{0 . \text { frontpass }}
\end{gathered}
$$

Here, $\mathrm{J}_{0 \text {.pass }}$ represents the saturation current density value of the area without the electrode on the solar cell surface and $\mathrm{f}$ represents the metal fraction. $\mathrm{J}_{0 \text {.metal }}$ value was extracted through a commonly used one-diode model, and it was assumed that the ideality factor $\mathrm{m}$ value was sufficiently ideal $(\mathrm{m}=1)$ to extract the $\mathrm{J}_{0 \text {.metal }}$ value using only the $\mathrm{J}_{0 . \text { total }}$ value $[8,16,17]$.

Then, $\mathrm{J}_{0 . m e t a l}$ was converted to surface recombination velocity $\left(\mathrm{S}_{\text {eff }}\right)$ to calculate the simulation. For this conversion, the following equation was used $[4,19]$.

$$
J_{0 . e m i t t e r}=J_{0 . \text { frontmetal }}(f)+J_{0 . \text { frontpass }}(1-f)
$$




$$
S_{e f f}=\frac{J_{0 . e m i t t e r} \cdot N_{A}}{q n_{i}^{2}}
$$

where, $S_{e f f}$ represents the surface recombination velocity, $\mathrm{J}_{0 . e m i t t e r}$ is the saturation leakage current of an emitter layer, $\mathrm{q}$ is the electronic charge, $\mathrm{n}_{i}$ the intrinsic carrier concentration and $N_{A}$ the doping concentration. The above two equations can be reorganized as follows.

$$
S_{\text {eff }}=\frac{\left[J_{0 . \text { frontmetal }}(f)+J_{0 . \text { frontpass }}(1-f)\right] \cdot N_{A}}{q n_{i}^{2}}
$$

Through the above equation, the relationship between $\mathrm{J}_{0 . m e t a l}$ and the surface recombination velocity can be represented, and the results obtained using the experiment and equation are illustrated below.

\section{Results and Discussion}

\subsection{Electrical Properties of the Perc Solar Cell}

For the simulation, two sample conditions, a PERC solar cell and a $\mathrm{J}_{0 . m e t a l}$ measurement sample, were fabricated and electric properties were measured with the prepared sample using the solar simulator (Light I-V), and Suns-Voc system. First, Figure 3 and Table 1 respectively show a graph and values of the PERC solar cell LIV measurements according to the firing temperature. As a result of LIV measurements, the open-circuit voltage of the sample decreased by about $1 \mathrm{mV}$ from $659.7 \mathrm{mV}\left(850{ }^{\circ} \mathrm{C}\right)$ to $658.8 \mathrm{mV}\left(900{ }^{\circ} \mathrm{C}\right)$ with the increase in the firing temperature. However, when the firing temperature was $950{ }^{\circ} \mathrm{C}$, the open-circuit voltage sharply decreased to $647.0 \mathrm{mV}$.

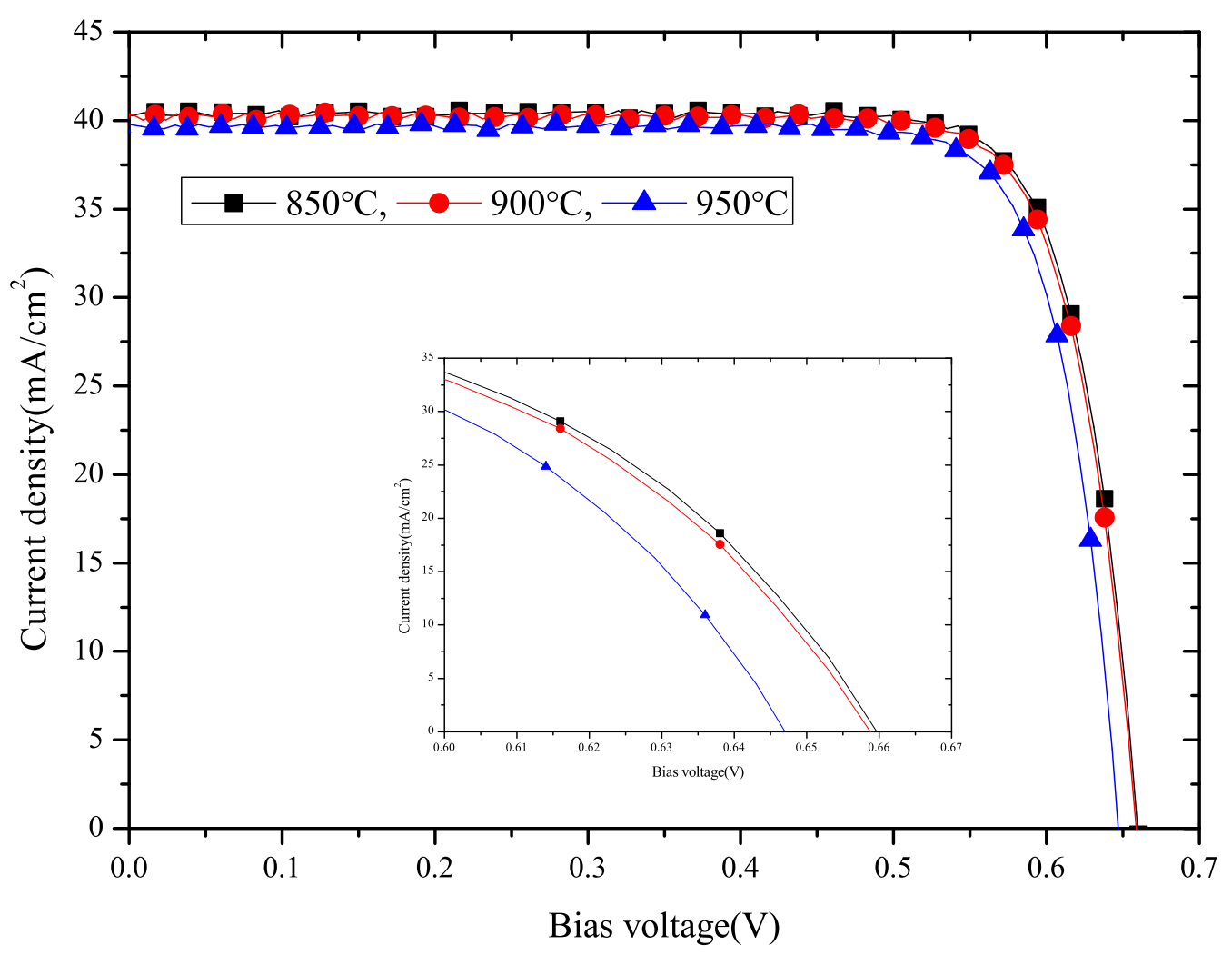

Figure 3. Light-biased current-voltage (LIV) results of the PERC solar cell depending on temperature conditions. 
Table 1. Results of the PERC solar cell LIV measurements for different firing temperatures, and a comparison with simulation.

\begin{tabular}{|c|c|c|c|c|c|c|}
\hline Firing Temperature $\left({ }^{\circ} \mathrm{C}\right)$ & $\mathrm{V}_{o c}(\mathrm{mV})$ & $\mathrm{J}_{s c}\left(\mathrm{~mA} / \mathrm{cm}^{2}\right)$ & FF (\%) & Eff. (\%) & $\mathrm{J}_{0 . m e t a l}\left(\mathrm{fA} / \mathrm{cm}^{2}\right)$ & $S_{e f f}(\mathrm{~cm} / \mathrm{s})$ \\
\hline 850 & 659.7 & 40.36 & 81.39 & 21.67 & 2165 & 353 \\
\hline 850-simul. & 659.67 & 40.3607 & 81.4437 & 21.6843 & - & 353 \\
\hline 900 & 658.8 & 40.26 & 81.21 & 21.54 & 2798 & 570 \\
\hline 900-simul. & 658.69 & 40.3604 & 81.4569 & 21.6553 & - & 570 \\
\hline 900-simul. modified & 658.79 & 40.3604 & 81.4562 & 21.6583 & - & 548.1 \\
\hline 950 & 647.0 & 39.68 & 81.30 & 20.87 & 3044 & 599 \\
\hline 950-simul. & 658.56 & 40.3603 & 81.4585 & 21.6515 & - & 599 \\
\hline 950-simul. modified & 647.0 & 40.3554 & 81.2785 & 21.2219 & - & 4287 \\
\hline
\end{tabular}

It was investigated whether the decrease in the open-circuit voltage due to the firing temperature change in the PERC solar cell is associated with the size and distribution of Ag crystallites. SEM analysis was performed on the Si surface to determine the shape of Ag crystallite with increasing firing temperature. The sample was immersed in $68 \%$ nitric acid for $15 \mathrm{~min}$ to remove the Ag bulk area, and the glass frit was removed by immersing it in a $10 \%$ hydrofluoric acid solution for $2 \mathrm{~min}$. Figure 4 shows the results of observing the size and distribution of Ag crystallites on the Si surface using SEM. It can be observed that the distribution and size of Ag crystallites on the Si surface increase as the firing temperature increases from $850^{\circ} \mathrm{C}$ to $950{ }^{\circ} \mathrm{C}$.

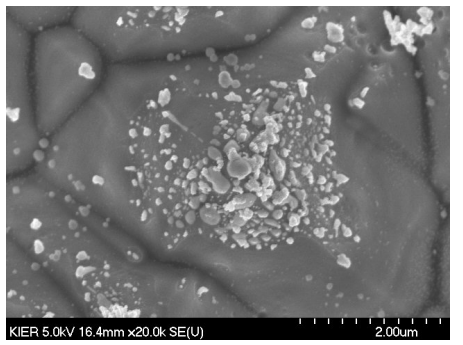

(a)

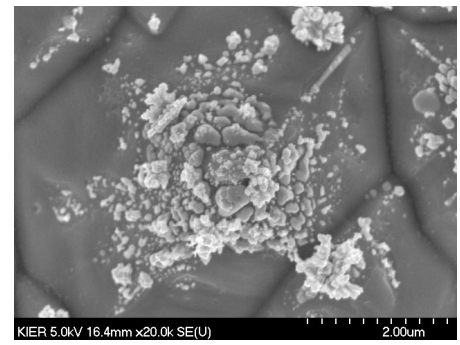

(b)

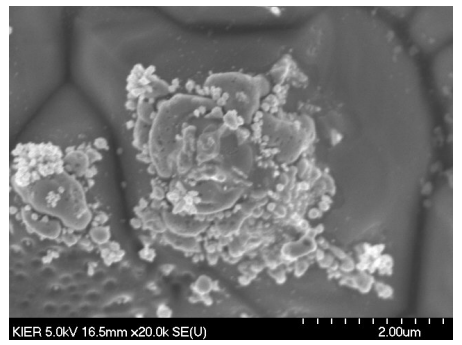

(c)

Figure 4. SEM images of Ag crystallite surface with the increase of temperature. (a) Firing temperature of $850{ }^{\circ} \mathrm{C},(\mathbf{b})$ firing temperature of $900{ }^{\circ} \mathrm{C}$, (c) firing temperature of $950{ }^{\circ} \mathrm{C}$.

When the temperature rises in the firing process, the glass frits mixed in the paste are fluidized, and the passivation layer is etched to react with $\mathrm{Si}$ on the solar cell surface. At this time, $\mathrm{Ag}^{+}$ions inside the glass frit react with $\mathrm{Si}$ to form $\mathrm{Ag}$ crystallites [20,21].

Since the diffusion rates of glass frits and $\mathrm{Ag}^{+}$ions increase with temperature, the size and distribution of $\mathrm{Ag}$ crystallites increase with the firing temperature. This agrees with the previous description of the increased size of the Ag crystallites as the firing temperature increased. This leads to the etching of the passivation layer and increasing the recombination velocity on the solar cell surface and reducing the open-circuit voltage in the contact surface area between $\mathrm{Si}$ and the metal. As shown in Figure 3, in the result of this experiment, the reason for the drop in the open-circuit voltage with increasing firing temperature was the increase in the size of $\mathrm{Ag}$ crystallites. In the case of Ag crystallite distribution, the distribution determination through the local SEM surface images alone is difficult, but it was reported in a prior study by the authors that it can be quantitatively analyzed that the firing temperature rise increases the size and distribution of Ag crystallites [22]. The surfaces of silicon solar cells have pyramid structure. During a diffusion process for emitter formation, the top position of the pyramid structure inevitably has a higher doping concentration than valley position. Generally knowns, emitter doping concentration affects on the Ag crystallite growth, so it can easily be formed on the top of the pyramid structure than slope and valley position [23]. Based on this result, it was analyzed that with the 
increase in the firing temperature, the increased Ag crystallites caused the increase in the surface recombination velocity and the consequent drop in the open-circuit voltage.

As shown in Figure 5, J0.metal of the PERC solar cell can be extracted by fitting the saturation current density value according to the metal fraction. Figure 5 shows that the saturation current density values according to the front electrode fraction at temperatures from $850{ }^{\circ} \mathrm{C}$ to $950^{\circ} \mathrm{C}$ were determined. The $\mathrm{J}_{0 . m e t a l}$ value was obtained using the respective temperature gradient values in the saturation current density graph, and these are listed in Table 1. The $\mathrm{J}_{0 . \text { metal }}$ value increased from $2165 \mathrm{fA} / \mathrm{cm}^{2}$ at $850{ }^{\circ} \mathrm{C}$ to $2798 \mathrm{fA} / \mathrm{cm}^{2}$ at $900{ }^{\circ} \mathrm{C}$, and further to $3044 \mathrm{fA} / \mathrm{cm}^{2}$ at $950{ }^{\circ} \mathrm{C}$. Using the extracted $\mathrm{J}_{0 . m e t a l}, \mathrm{~S}_{\text {eff }}$ was calculated through Equation (5), and the result showed a gradual increase at $353 \mathrm{~cm} / \mathrm{s}, 570 \mathrm{~cm} / \mathrm{s}$, and $599 \mathrm{~cm} / \mathrm{s}$, respectively.

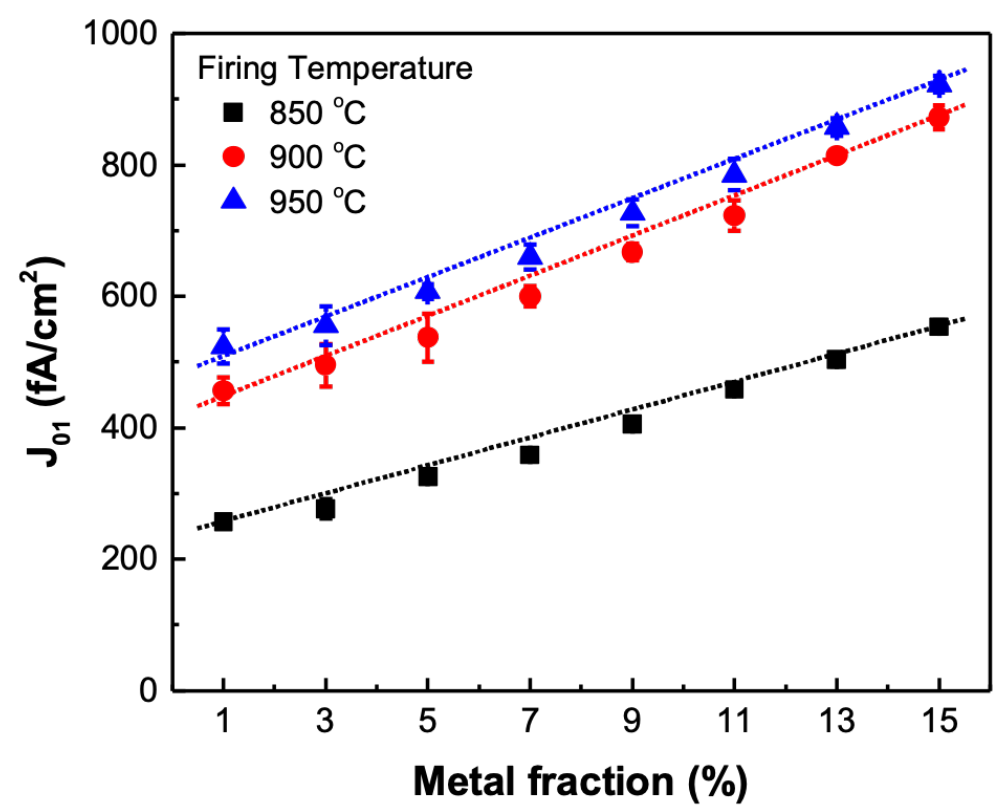

Figure 5. $\mathrm{J}_{01}$ vs. the metal fraction on the front electrode fraction.

This result supports the relationship between the size of Ag crystallites and firing temperature discussed above and shows that the surface recombination velocity values may differ depending on the growth environment of Ag crystallites. However, considering the above results, although the saturation current density between $900{ }^{\circ} \mathrm{C}$ and $950{ }^{\circ} \mathrm{C}$ changed less than the saturation current density change between $850^{\circ} \mathrm{C}$ and $950{ }^{\circ} \mathrm{C}$, in Figure 3 , at $950{ }^{\circ} \mathrm{C}$, more pronounced drop in the open-circuit voltage can be seen. To analyze these aspects, a numerical analysis simulation was performed to examine the effect of the change in Ag crystallites under ideal conditions.

\subsection{Simulation Results}

Using a numerical simulation model, the effect of the change in surface recombination velocity on the solar cell performance was calculated and illustrated in Figure 6. For simplified representation of the complex recombination correlation inside the PERC solar cell, LIV data at $850^{\circ} \mathrm{C}$ was used as a reference. The difference in the surface recombination velocity values at $900{ }^{\circ} \mathrm{C}$ and $950{ }^{\circ} \mathrm{C}$ from the reference value at $850{ }^{\circ} \mathrm{C}$ was used for the analysis of the effect on the solar cell performance. As shown in Table 1 , at $850^{\circ} \mathrm{C}$, the experimental and simulation results showed good agreement with each other. In this condition, the surface recombination velocity was set to be $570 \mathrm{~cm} / \mathrm{s}$ to apply the surface recombination state at $950{ }^{\circ} \mathrm{C}$, and the result showed a very similar pattern to the trend of actually measured LIV values when the firing temperature increased from $850^{\circ} \mathrm{C}$ to $900{ }^{\circ} \mathrm{C}$. 


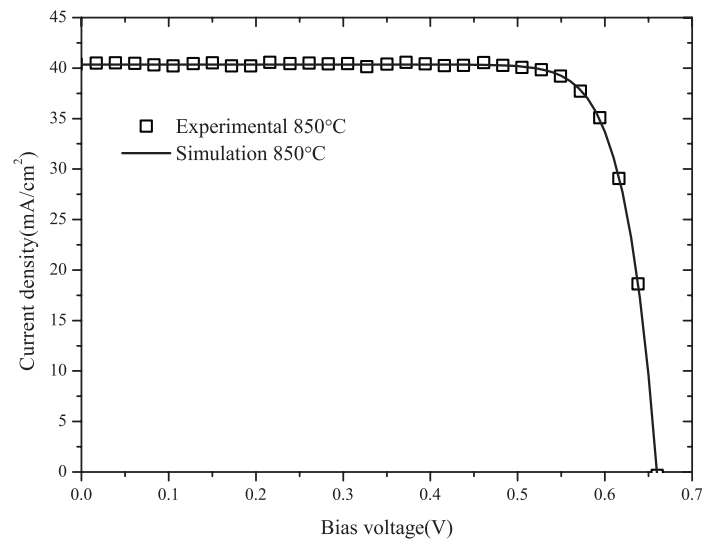

(a)

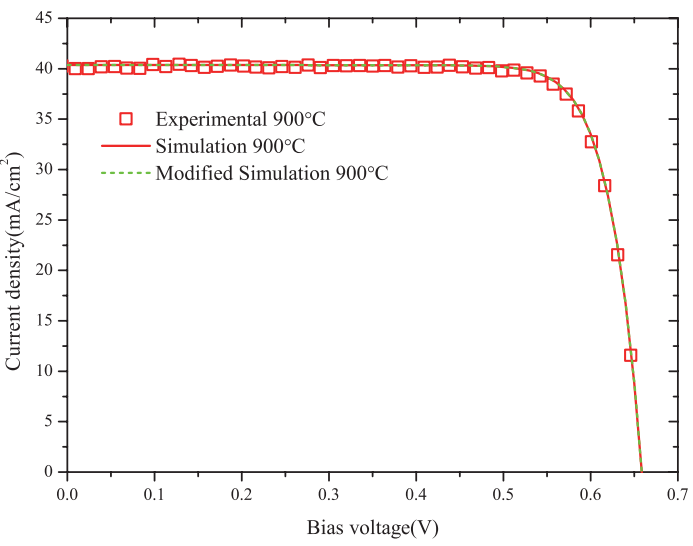

(b)

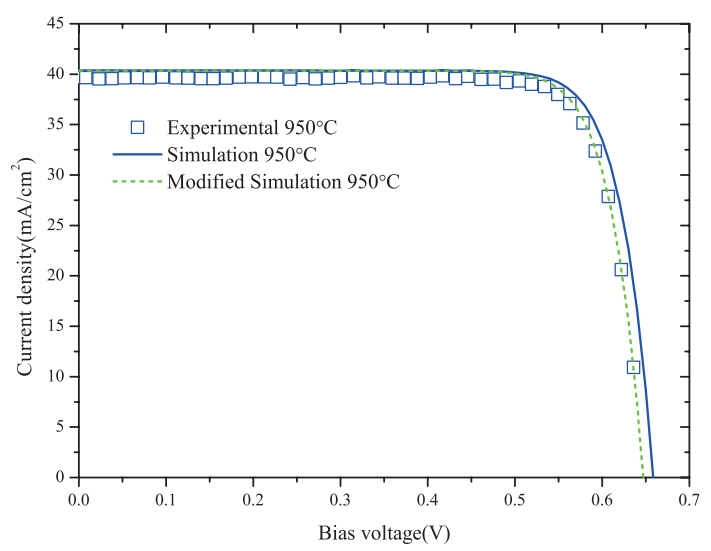

(c)

Figure 6. LIV data compared to numerical simulation results for the PERC solar cells. (a) Firing temperature $850{ }^{\circ} \mathrm{C}$, (b) firing temperature $900{ }^{\circ} \mathrm{C}$, (c) firing temperature $950{ }^{\circ} \mathrm{C}$.

Since the two sets of values are not exactly the same, the surface recombination velocity extracted by fitting the $900{ }^{\circ} \mathrm{C}$ LIV data obtained from the experimental measurement in the simulation shows a value of $548.1 \mathrm{~cm} / \mathrm{s}$. This indicates a difference of only $21.9 \mathrm{~cm} / \mathrm{s}$ compared to the estimated value at $570 \mathrm{~cm} / \mathrm{s}$ in the calculation, which suggests an error of approximately $3.84 \%$. As the simulation result showed a similar pattern to the surface recombination velocity changes of $\mathrm{Ag}$ crystallites obtained by experimental measurements, it is considered that the recombination properties of Ag crystallites have induced changes in the PERC solar cell performance.

The trend shown at $900{ }^{\circ} \mathrm{C}$ is different from that observed at $950{ }^{\circ} \mathrm{C}$. In the sample for the $\mathrm{J}_{0 \text { measurement, }}$ when the extracted value of the surface recombination velocity was used in the simulation at the $950{ }^{\circ} \mathrm{C}$ condition, the simulation result was not consistent with the LIV data of the PERC solar cell at $950{ }^{\circ} \mathrm{C}$. The open-circuit voltage of the $950{ }^{\circ} \mathrm{C}$ PERC solar cell is $647.0 \mathrm{mV}$, and the value calculated through the simulation is $658.56 \mathrm{mV}$, showing a difference of $11.56 \mathrm{mV}$, indicating an error at $1.79 \%$. This corresponds to a 107 -fold increase in error compared to an error of $0.017 \%$ at $900{ }^{\circ} \mathrm{C}$. To analyze the sharp error increase, a simulation fitting was conducted to obtain the consistent value with the LIV data of the $950^{\circ} \mathrm{C}$ PERC solar cell, and, in this case, the extracted surface recombination velocity is calculated at $4287 \mathrm{~cm} / \mathrm{s}$ (see the modified simulation $950{ }^{\circ} \mathrm{C}$ in Figure 6 and 950-simul.modified in Table 1). This corresponds to a difference of $3688 \mathrm{~cm} / \mathrm{s}$ compared to the measurement data, and this difference is considered to be due to factors other than the characteristics of Ag crystallites occurring in the electrode. In the Jomeasurement sample, the possibility of over fire occurrence is considered to be smaller than the sample for the PERC solar cell, and in the actual process of PERC solar cell fabrication, it was considered 
that the emitter layer of the solar cell is damaged due to over fire. It is speculated that the leakage current from the damaged emitter layer has caused the rapid increase in the overall surface recombination velocity of the solar cell.

Based on these results, the characteristics of Ag crystallites in the front electrode of the solar cell were analyzed, and the recombination properties of Ag crystallites according to the temperatures in the firing process were defined, which enabled the investigation of the effect of the surface recombination on the performance of the PERC solar cell. In conclusion, for Ag crystallites, compared to other measures, such as improving the contact resistance, surface recombination is the main driver in reducing the open-circuit voltage of the solar cells. Therefore, by suppressing the formation of Ag crystallites and minimizing its occurrence, the surface recombination on the front electrode will be reduced, enabling the fabrication of highly efficient solar cells. In addition, the formation of excessive Ag crystallites is highly likely to cause a sharp increase in the recombination velocity from the front emitter damage, and in this regard, measures to improve the temperature condition control are imperative.

\section{Conclusions}

This study investigated the distribution of Ag crystallites, saturation current density, surface recombination velocity, and changes in the performance of PERC solar cells at the silicon-metal interface for different firing temperatures. Furthermore, TCAD simulation was employed for in-depth analysis of factors degrading the solar cell performance. The experimental results confirmed that as the firing temperature increased from $850{ }^{\circ} \mathrm{C}$ to $950{ }^{\circ} \mathrm{C}$, the distribution of Ag crystallites increased, leading to an increase in the surface recombination velocity at the silicon-electrode interface. The open-circuit voltage of PERC solar cells decreased with increasing firing temperature, indicating that the performance degradation of solar cells can be attributed to the increase in the distribution of Ag crystallites and the consequent increase in the surface recombination velocity. The in-depth analysis on the cause of the performance degradation of the solar cell using TCAD simulation showed that at temperatures of $850-900{ }^{\circ} \mathrm{C}$, the analysis results showed that the increase in the surface recombination velocity due to the increased distribution of Ag crystallites caused the changes in the open-circuit voltage of the PERC solar cell, whereas at temperatures of 900-950 ${ }^{\circ} \mathrm{C}$, over fire from the emitter damage was the main cause of the sharp decrease in the open-circuit voltage. These results are expected to provide a useful contribution to future research on the improvement of silicon solar cell performance by controlling firing temperature and changing Ag crystallites distribution in the field of PERC solar cell manufacturing and research.

Author Contributions: Conceptualization, M.S.J., M.G.K. and S.M.K.; methodology, M.S.J. and Y.L.; software, M.S.J., Y.L., S.M.K. and K.-H.K.; validation, M.S.J., Y.L. and S.M.K.; formal analysis, M.S.J. and S.C.; investigation, M.S.J. and M.G.K.; data curation, M.S.J., M.G.K. and S.M.K.; writingoriginal draft preparation, M.S.J., Y.L. and S.M.K.; writing-review and editing, S.M.K. and H.-e.S.; visualization, M.S.J. and S.M.K. All authors have read and agreed to the published version of the manuscript.

Funding: This research received no external funding.

Acknowledgments: This work was supported by the Korea Institute of Energy Technology Evaluation and Planning (KETEP) and the Ministry of Trade, Industry \& Energy (MOTIE) of the Republic of Korea (No. 20183010014320) \& (No. 20183010013880). This work was supported by the National Research Foundation of Korea(NRF) grant funded by the Korea government(MSIT) (No. 2020R1A2C1099974) and was conducted under the framework of the Research and Development Program of the Korea Institute of Energy Research (B7-2426). This research was also supported by a grant(The core project-564) from Gumi Core Components and Materials Technology Development Program of the Gumi Regional Government, 2020.

Conflicts of Interest: The authors declare no conflict of interest. 


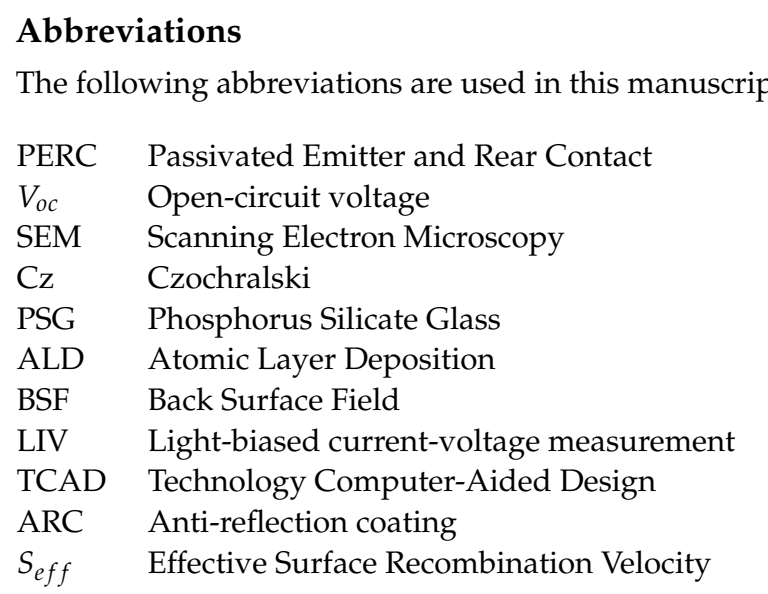

\section{References}

1. Feldmann, F.; Bivour, M.; Reichel, C.; Hermle, M.; Glunz, S.W. Passivated rear contacts for high-efficiency n-type Si solar cells providing high interface passivation quality and excellent transport characteristics. Sol. Energy Mater. Sol. Cells 2014, 120, 270-274. [CrossRef]

2. Meier, S.; Wasmer, S.; Fell, A.; Wöhrle, N.; Greulich, J.; Wolf, A. Efficiency Potential of p-type PERT vs. PERC Solar Cells. In Proceedings of the 2018 IEEE 7th World Conference on Photovoltaic Energy Conversion (WCPEC) (a Joint Conference of 45th IEEE PVSC, 28th PVSEC \& 34th EU PVSEC), Waikoloa Village, HI, USA, 10-15 June 2018; pp. 3578-3583.

3. Fischer, M. ITRPV 10th edition 2019-report release and key findings. Technical report. In Proceedings of the PV Cell Tech Conference, Penang, Malaysia, 12-13 March 2019.

4. Hannebauer, H.; Sommerfeld, M.; Müller, J.; Dullweber, T.; Brendel, R. Analysis of the emitter saturation current density of industrial type silver screen-printed front contacts. In Proceedings of the 27th EU PVSEC, Frankfurt, Germany, 24-28 September 2012; Volume 1360.

5. Min, B.; Dastgheib-Shirazi, A.; Altermatt, P.; Kurz, H. Accurate determination of the emitter saturation current density for industrial P-diffused emitters. In Proceedings of the 29th EU PV Energy Conference, Amsterdam, The Netherlands, 22-26 September 2014; p. 463.

6. Hoenig, R.; Glatthaar, M.; Clement, F.; Greulich, J.; Wilde, J.; Biro, D. New measurement method for the investigation of space charge region recombination losses induced by the metallization of silicon solar cells. Energy Procedia 2011, 8, 694-699. [CrossRef]

7. Müller, J.; Bothe, K.; Gatz, S.; Haase, F.; Mader, C.; Brendel, R. Recombination at laser-processed local base contacts by dynamic infrared lifetime mapping. J. Appl. Phys. 2010, 108, 124513. [CrossRef]

8. Edler, A.; Mihailetchi, V.D.; Koduvelikulathu, L.J.; Comparotto, C.; Kopecek, R.; Harney, R. Metallization-induced recombination losses of bifacial silicon solar cells. Prog. Photovolt. Res. Appl. 2015, 23, 620-627. [CrossRef]

9. Reichel, C.; Granek, F.; Benick, J.; Schultz-Wittmann, O.; Glunz, S. Comparison of emitter saturation current densities determined by injection-dependent lifetime spectroscopy in high and low injection regimes. Prog. Photovolt. Res. Appl. 2012, 20, 21-30. [CrossRef]

10. Ballif, C.; Huljić, D.; Willeke, G.; Hessler-Wyser, A. Silver thick-film contacts on highly doped n-type silicon emitters: Structural and electronic properties of the interface. Appl. Phys. Lett. 2003, 82, 1878-1880. [CrossRef]

11. Schubert, G.; Huster, F.; Fath, P. Physical understanding of printed thick-film front contacts of crystalline Si solar cells-Review of existing models and recent developments. Sol. Energy Mater. Sol. Cells 2006, 90, 3399-3406. [CrossRef]

12. Hilali, M.M.; Sridharan, S.; Khadilkar, C.; Shaikh, A.; Rohatgi, A.; Kim, S. Effect of glass frit chemistry on the physical and electrical properties of thick-film Ag contacts for silicon solar cells. J. Electron. Mater. 2006, 35, 2041-2047. [CrossRef]

13. Vinod, P. Specific contact resistance and carrier tunneling properties of the silver metal/porous silicon/p-Si ohmic contact structure. J. Alloys Compd. 2009, 470, 393-396. [CrossRef]

14. Hörteis, M.; Gutberlet, T.; Reller, A.; Glunz, S.W. High-temperature contact formation on n-type silicon: Basic reactions and contact model for seed-layer contacts. Adv. Funct. Mater. 2010, 20, 476-484. [CrossRef]

15. Shanmugam, V.; Khanna, A.; Basu, P.K.; Aberle, A.G.; Mueller, T.; Wong, J. Impact of the phosphorus emitter doping profile on metal contact recombination of silicon wafer solar cells. Sol. Energy Mater. Sol. Cells 2016, 147, 171-176. [CrossRef]

16. Inns, D.; Poplavskyy, D. Measurement of metal induced recombination in solar cells. In Proceedings of the 2015 IEEE 42 nd Photovoltaic Specialist Conference (PVSC), New Orleans, LA, USA, 14-19 June 2015; pp. 1-4.

17. Fellmeth, T.; Born, A.; Kimmerle, A.; Clement, F.; Biro, D.; Preu, R. Recombination at metal-emitter interfaces of front contact technologies for highly efficient silicon solar cells. Energy Procedia 2011, 8, 115-121. [CrossRef]

18. Grupp, G.; Huljic, D.; Preu, R.; Willeke, G.; Luther, J. Peak firing temperature dependence of the microstructure of ag thick-film contacts on silicon solar cells-a detailed afm study of the interface. In Proceedings of the 20th EC PVSEC, Barcelona, Spain, 6-10 June 2005.

19. Aberle, A.G. Surface passivation of crystalline silicon solar cells: A review. Prog. Photovolt. Res. Appl. 2000, 8, 473-487. [CrossRef]

20. Hong, K.K.; Cho, S.B.; You, J.S.; Jeong, J.W.; Bea, S.M.; Huh, J.Y. Mechanism for the formation of Ag crystallites in the Ag thick-film contacts of crystalline Si solar cells. Sol. Energy Mater. Sol. Cells 2009, 93, 898-904. [CrossRef] 
21. Qin, J.; Zhang, W.; Bai, S.; Liu, Z. Study on the sintering and contact formation process of silver front side metallization pastes for crystalline silicon solar cells. Appl. Surf. Sci. 2016, 376, 52-61. [CrossRef]

22. Jeong, M.S.; Min, K.H.; Choi, S.; Kang, M.G.; Jeong, K.T.; Lee, E.T.; Kang, Y.; Kim, D.; Lee, H.S.; Song, H.E.; et al. Correlation between the open-circuit voltage and recombination loss at metal-silicon interfaces of crystalline silicon solar cells. Sol. Energy Mater. Sol. Cells 2020, 210, 110519. [CrossRef]

23. Cabrera, E.; Olibet, S.; Rudolph, D.; Vullum, P.E.; Kopecek, R.; Reinke, D.; Herzog, C.; Schwaderer, D.; Schubert, G. Impact of excess phosphorus doping and Si crystalline defects on Ag crystallite nucleation and growth in silver screen-printed Si solar cells. Prog. Photovolt. Res. Appl. 2015, 23, 367-375. [CrossRef] 